\title{
Studies on the Phytochemical Composition and Antioxidant Activity of a Prunus spinosa L. Aqueous Extract
}

\author{
GABRIELA GEGIU ${ }^{1}$, LAURA BUCUR ${ }^{1 *}$, ANTOANELA POPESCU ${ }^{1}$, MARIUS-DANIEL RADU ${ }^{1}$, \\ SEBASTIAN MIHAI ${ }^{1}$, VICTORIA BADEA ${ }^{2}$ \\ ${ }^{1}$ Ovidius University of Constanta, Faculty of Pharmacy, 6 Capitan Al. Serbanescu Str., 900470, Constanta, Romania \\ ${ }^{2}$ Ovidius University of Constanta, Faculty of Dental Medicine, 7 Ilarie Voronca Str., 900648, Constanta, Romania
}

The purpose of this study was to analyze the phenolic compounds and the antioxidant activity of the aqueous extract obtained from the fruit of Prunus spinosa $L$.. The aqueous extract of $10 \%$ concentration was obtained from the pulp of dried fruits, harvested from Tulcea county, Romania. The tannin content was $3.38 \mathrm{~g} \%$ and the total polyphenols $6.95 \mathrm{~g} \%$. Based on the HPLC analysis, the identified polyphenolic acids were chlorogenic acid, caffeic acid and gallic acid and the concentrations in mg per 100g of fruit pulp powder were 15.174, 10.93 and 81.468, respectively. The $100 \mathrm{mg} / \mathrm{mL}$ aqueous extract had a high DPPH radical scavenger ability (87.30\%) which correlated with the polyphenol content and supports the possibility of using rich bioactive aqueous extracts for oxidative stress related conditions.

Keywords: Prunus spinosa L., aqueous extract, total polyphenols, antioxidant activity, DPPH scavenger

The use of medicinal plants could be an important solution for the future of medicine, as plant based bioactive compounds are not exploited to their full potential [1,2]. Currently, it's estimated that approximately $50 \%$ of all modern drugs are of natural origin [3]. Since antiquity, many plant species have been used to combat pathogens due to antioxidant and antimicrobial properties generated by glycosides, saponosides, flavonosides, sterolic heterosides, tannins, alkaloids, and terpenes [4]. Prunus spinosa L. has been known since ancient times, with ethnobotanical uses that ranged from obtaining dyies to decoctions used for treating tooth sores. The decoction obtained from crushed fruit kernels or the decoction obtained from roots and fruits was used in the treatment of diarrhea [5].

Prunus spinosa L. is classified in the Magnoliophyta rank, Magnoliatae class, Rosidae subclass, Rosales order, Rosaceae family, Prunoidae subfamily, Prunus genus [6, 7]. The assesment of its phytochemical composition as well as fruit antioxidant capacity were made in other studies, and showed the presence of vitamin C, polyphenols, flavonosides, anthocyanosides and carotenoids [8-10]. The purpose of this study is the evaluation of total tannin content, polyphenol content and antioxidant capacity of a aqueous extract obtained from Prunus spinosa L. fruits harvested in Tulcea County, Romania.

\section{Experimental part}

Materials and methods

The plant material used was the pulp of dried fruits of Prunus spinosa L. harvested in Tulcea County, Romania. The fruits were picked manually in autumn, in September, between $5^{\text {th }}$ and $11^{\text {th }}$ day of the month, when the tannin content is highest [11]. The plant product consisting of the pulp separated from the kernel was dehydrated at $30^{\circ} \mathrm{C}$ and ground into a fine powder. The methods used were as follows: the loss by drying assayed according to the monograph in the Romanian Pharmacopoeia, 10th edition (FR X) [12] and the European Pharmacopoeia, 9th edition (EP 9) [13].

Obtaining the aqueous extract

The preparation of the $10 \%$ aqueous extract was carried out as follows: $10.004 \mathrm{~g}$ of pulp powder of dried Prunus spinosa L. fruits were extracted with $100 \mathrm{~mL}$ of water by reflux for 30 minutes at a temperature of $70^{\circ} \mathrm{C}$. The raw extract was filtered and brought to volume with water in a $100 \mathrm{~mL}$ volumetric flask.

Determination of total tannin and polyphenol content

The tannin content was determined by the Folin-Ciocâlteu method according to EP 9 and the determination of total polyphenols was done by the Folin-Ciocâlteu method according to an adapted EP 9 method. Briefly, $10 \mathrm{~mL}$ of a $2 \%$ aqueous extract were stirred for 60 minutes with $0.10 \mathrm{~g}$ skin powder and then filtered through no 42 Whatman paper. $2 \mathrm{~mL}$ of this solution were added to $1 \mathrm{~mL}$ Folin Ciocalteu Reagent, $10 \mathrm{~mL}$ double distilled water an $17 \mathrm{~mL} \mathrm{Na} \mathrm{CO}_{3} 290 \mathrm{~g} / \mathrm{L}$ solution.

*email: adrianabucur@yahoo.com

Rev. Chim. $71 \bullet$ no. $2 \bullet 2020 \bullet$ https://revistadechimie.ro 
The absorbance of a $3 \mathrm{~mL}$ sample of this solution was read after 30 minutes at $760 \mathrm{~nm}$. The tannin content was calculated according to the formula:

$$
\% \text { tannins }=\frac{62.5 \times\left(A_{1}-A_{2}\right) \times m_{2}}{A_{3} \times m_{1}}
$$

where, $\mathrm{m}_{1}=$ mass of the sample examined $(\mathrm{g}) ; \mathrm{m}_{2}=$ pyrogallol mass $(\mathrm{g}) ; \mathrm{A}_{1}=$ total polyphenols absorbance; $\mathrm{A}_{2}=$ absorbance of non-adsorbed poliphenols on the skin powder; $\mathrm{A}_{3}=$ absorbance of the pyrogallol standard.

For polyphenols, the same method was used, with the required adaptations. Briefly, $2 \mathrm{~mL}$ of the analysed solution $(2 \%$ aqueous extract) were vortexed with $1 \mathrm{~mL}$ Folin Ciocalteu reagent, to wich $10 \mathrm{~mL}$ of double distilled water and $17 \mathrm{~mL}$ $\mathrm{Na}_{2} \mathrm{CO}_{3} 290 \mathrm{~g} / \mathrm{L}$ solution were added. The reaction mixture was left standing for 30 minutes and the absorbance of a $3 \mathrm{~mL}$ sample was read at $760 \mathrm{nmThe}$ total polyphenol content was calculated according to the formula:

$$
\% \text { total polyphenols }=\frac{62.5 \times A_{1} \times m_{2}}{A_{3} \times m_{1}}
$$

where, $\mathrm{m}_{1}=$ mass of the sample examined $(\mathrm{g}) ; \mathrm{m}_{2}=$ pyrogallol mass $(\mathrm{g}) ; \mathrm{A}_{1}=$ total polyphenols absorbance; $\mathrm{A}_{2}=$ absorbance of non-absorbed poliphenols on the ground powder.

Determination of absorbances was performed on the UV-VIS Jasco V630 spectrophotometer.

Identification and quantification by HPLC analysis of polyphenols of Prunus spinosa L.

Separation, identification and quantification of phenolic compounds was performed by a standardized HPLC method for the determination of total polyphenols, according to the USP 30-NF25 monograph. A Agilent 1200 HPLC Chromatogram with quaternary pump, DAD, thermostat, degassing system, autosampler was employed. Working conditions included chromatographic column type $\mathrm{C} 18,250 \mathrm{~mm} \times 4.6 \mathrm{~mm} ; 5 \mu \mathrm{m}$ (Zorbax XDB); mobile phase: solution A - 0.1\% phosphoric acid, solution $\mathrm{B}$ - acetonitrile; gradient elution according to Table 1 ; temperature: $35^{\circ} \mathrm{C}$, flow: $1.5 \mathrm{~mL} / \mathrm{min}$, detection: UV $310 \mathrm{~nm}$, injection volume: $20 \mu \mathrm{L}$, assay time: 22 minutes.

Table 1

HPLC GRADIENT

\begin{tabular}{|c|c|c|}
\hline Time (min) & Solution A (\%) & Solution B (\%) \\
\hline $0-13$ & 90 & 10 \\
\hline 13 & 78 & 22 \\
\hline 13 & 78 & 22 \\
\hline 14 & 60 & 40 \\
\hline 17 & 60 & 40 \\
\hline 17.5 & 90 & 10 \\
\hline 22 & 90 & 10 \\
\hline
\end{tabular}

Separation, identification and quantification of some of the polyphenols in Prunus spinosa L. by the HPLC method was performed using external standards. Eight standard substances (70\% methanol solutions) were employed and were of analytical grade, pruchased from Chromadex: $E$-resveratrol $=0.37 \mathrm{mg} / \mathrm{mL}$, caffeic acid $=0.36 \mathrm{mg} / \mathrm{mL}$, chlorogenic acid $=$ $0.37 \mathrm{mg} / \mathrm{mL}$, cinnamic acid $=0.58 \mathrm{mg} \mathrm{mL}$, vanillin $=0.42 \mathrm{mg} / \mathrm{mL}$, gallic acid $=0.39 \mathrm{mg} / \mathrm{mL}$, ferulic acid $=0.38 \mathrm{mg} / \mathrm{mL}$, 3-methyl gallic acid $=0.51 \mathrm{mg} / \mathrm{mL}$.

The reference substances were injected 6 times $(20 \mu \mathrm{L})$. The identification of polyphenolic compounds was done based on the retention times of the standards. The quantification of the extract's bioactive compounds was done by linear interpolation after drawing a regression curve for dilutions of the standard solutions $\left(R^{2}>0.99\right)$.

Determination of DPPH free radical scavenger ability

The DPPH (2,2-diphenyl-1-picrylhydrazyl) method is specific for assessing the ability to inactivate free radicals by phenolic compounds [8]. The purple color of the DPPH solution at $517 \mathrm{~nm}$ changes to pale yellow due to the appearance of the reduced form of the free radical after contact with the sample solution containing active principles with free radical scavenging potential. The method used was decribed in a previous study [14], and the total scavenging ability of the extract was calculated with the following equation: 
$\%$ scavenger activity $=100 \times\left(\mathrm{A}_{\text {initial }}-\mathrm{A}_{\text {final }}\right) / \mathrm{A}_{\text {initial }}$,

where: $\mathrm{A}_{\text {initial }}=$ Absorbance before addition of the plant extract and $\mathrm{A}_{\text {final }}=$ absorbance 15 minutes after addition of the solution to be analyzed. The IC50 (concentration of plant extract that scavenges 50\% of the free radical) was calculated using the linear regression method and is expressed by constructing the dose-response curve [15].

\section{$\underline{\text { Statistical analysis }}$}

The data sets were analyzed using the ANOVA test and the significance of the results was analyzed using the Student T-Test $(\mathrm{p}<0.05)$. All experiments were performed in triplicate and the results were expressed as mean \pm standard deviation. We used Pearson correlation $r$ coefficient to measure the degree of linkage between the total polyphenolic content and the minimum inhibitory concentration for $50 \%$ of the DPPH free radical. The statistical analysis was obtained by processing the data using SPSS 18 (IBM).

\section{Results and discussions}

Determination of loss by drying

As a result of drying loss in the oven, values of $11.59 \% \pm 0.07$ were obtained. These results fall within the limits mentioned in the literature, at most $12 \%$ for this type of fruit [16].

\section{Determination of total tannin and polyphenol content}

The total phenolic content of Prunus spinosa L. fruit aqueous extract was $6.94 \pm 0.005 \mathrm{~g} \%$ and the tannin content was $3.37 \pm 0.01 \mathrm{~g} \%$. In a study conducted by Pinacho et al., a total polyphenol content of $327.02 \pm 4.66 \mathrm{mg} / \mathrm{g}$ was correlated with a strong antioxidant effect [17]. Another serbian study on the Prunus spinosa L. fruit extract showed a high content of polyphenols (11.24-18.70 g GAE/kg) [18].

\section{Identification and quantification of polyphenols by HPLC analysis}

Several bioactive compounds were identified and quantified by HPLC. The following polyphenolic compounds were identified and quantified: chlorogenic acid, caffeic acid and gallic acid (Chart 1). All compounds detected by the HPLC method are recognized for antioxidant and antimicrobial properties [16, 19-21].

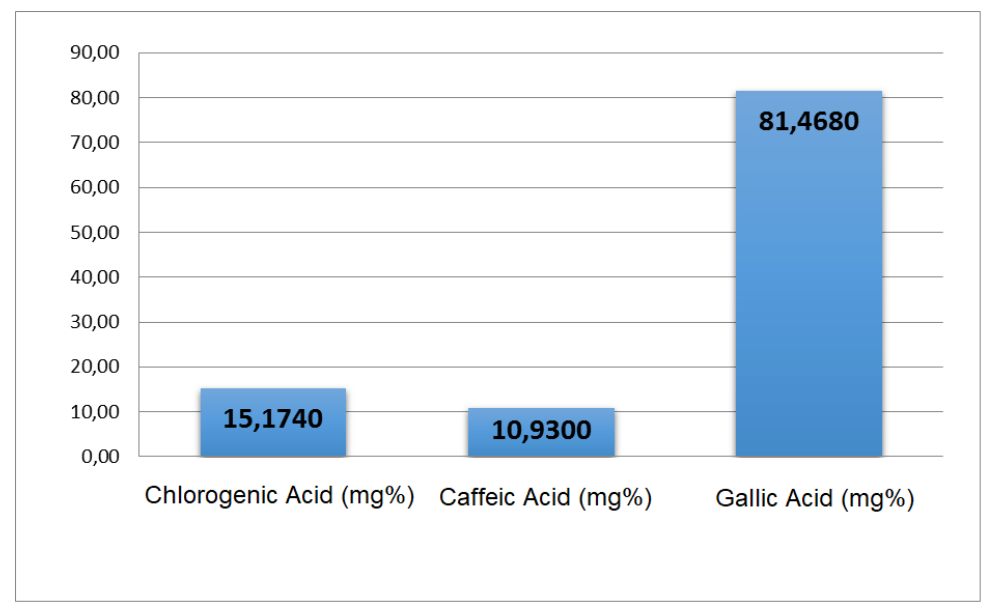

\author{
Chart 1. Graphical \\ representation of the \\ content in polyphenolic \\ compounds identified in \\ the aqueous extract
}

In similar studies conducted by Velickovic et al., caffeic acid, which we identified in the present study [8], was not found. Studies carried out by Rodriguez et al. on Prunus spinosa L. showed the presence of very high concentrations of gallic acid (430.38-985.56 mg/100g) [22], which are comparable to those found in this study $(81.46 \mathrm{mg} / 100 \mathrm{~g})$. Gallic acid was identified in the Radovanovic study in a higher concentration $(150.21 \mathrm{mg} / 100 \mathrm{~g})$, while the concentration of caffeic acid was lower in the study of the same author $(0.34 \mathrm{mg} / 100 \mathrm{~g})$ [9]. Also, in the Pinacho study, gallic acid was identified in the concentration of $0.2226 \mathrm{mg} / 100 \mathrm{~g}$ and caffeic acid in the concentration of $0.1272 \mathrm{mg} / 100 \mathrm{~g}$ [17]. The analysis of polyphenolic compounds by Celik et al. showed the presence of chlorogenic acid at $1.2985 \mathrm{mg} / 100 \mathrm{~g}$ [23]. The differences between polyphenol concentrations mentioned above may be linked to the pedoclimatic conditions. 
Determination of DPPH free radical scavenging ability

The aqueous extract obtained from fruits harvested in Tulcea County showed a high DPPH scavenging ability (87.08\%) at a concentration of $100 \mathrm{mg} / \mathrm{mL}$; the results are ilustrated in Table 2.

Table 2

SAMPLE SCAVENGING ABILITY

\begin{tabular}{|c|c|c|c|}
\hline Sample/Control & $\begin{array}{c}\text { Concentration } \\
(\mathrm{mg} / \mathrm{mL})\end{array}$ & \% scavenging ability & $\begin{array}{l}\text { I.C. 50 } \\
(\mathrm{mg} / \mathrm{ml})\end{array}$ \\
\hline \multirow[t]{4}{*}{ Aqueous extract } & 100 & $87.08 \pm 0.34$ & \multirow{4}{*}{$19.57 \pm 0.61$} \\
\hline & 50 & $65.04 \pm 0.81$ & \\
\hline & 25 & $52.20 \pm 0.90$ & \\
\hline & 12.5 & $46.54 \pm 0.67$ & \\
\hline \multirow[t]{4}{*}{ Gallic acid } & 20 & $95.42 \pm 0.02$ & \multirow{4}{*}{$<0.001$} \\
\hline & 10 & $94.02 \pm 0.54$ & \\
\hline & 5 & $94.20 \pm 0.10$ & \\
\hline & 2.5 & $93.57 \pm 0.02$ & \\
\hline
\end{tabular}

The radical scavenging ability assayed by the DPPH method has been studied for Prunus spinosa L. by several authors. The obtained results were similar to those presented by Velickovic et al., who highlighted an antioxidant activity value ranging from $32.05 \%$ to $89.10 \%$ [8]. Radovanovic et al. also employed a similar method for a aqueous extract of Prunus spinosa L. fruits, however the authors obtained a lower free radical scavenging ability (27.06\%) [9]. In a study conducted by Natic et. al., the authors found a high antioxidant activity $(180.93-267.11 \mathrm{mMTE} / \mathrm{mL})$, measured by the DPPH method [18]. The minimum inhibitory concentration of Prunus spinosa L. aqueous extract was $19.57 \pm 0.61 \mathrm{mg} / \mathrm{mL}$ which, although higher than that of the standard employed is significantly low.

A statistically significant negative correlation between the total polyphenolic content determined by the Folin-Ciocalteu method and the minimum inhibitory concentration for $50 \%$ of the DPPH free radical $(r=-0.92135, p<0.05)$ was obtained.

\section{Conclusions}

The existence of tannins in the composition of dried fruits of Prunus spinosa L. harvested in Tulcea County may justify further studies of the plant material for the evaluation of some pharmacological properties. The presence of polyphenols in the fruit pulp of Prunus spinosa L. explains the proven antioxidant properties and supports the possibility of using active principles in conditions caused by the presence of free radicals. Antioxidant properties assessed by evaluating the DPPH radical scavenger capacity correlate with the content of polyphenols.

\section{References}

1.IBRAHIM, N. M., MAT, I., LIM, V., AHMAD, R., Antioxidants, 2013, 2, no. 3, p. 156-166.

2.MALHERBE, C. J., DE BEER, D., JOUBERT, E., Int. J. Mol. Sci, 2012, 13, no. 3, p. 3101-3133.

3.BUKAR, A. M., ISA, M. A., BELLO, H. S., ABDULLAHI, A. S., Int. J. Environ. Res., 2013, 2, no. 1, p. 147-152.

4.ERUMALlA, V., SOLDEVANAHALli, H., GOLI, D., CHENNA, S., Int. J. Pharm. Res. Sci., 2014, 2, no. 4, p. $284-289$.

5.PARVU, C., Enciclopedia plantelor - Plante din Flora Romaniei, vol. IV, Editura Tehnica, Bucuresti, 2005, p. 135-138.

6.CIOCARLAN, V., Flora ilustrata a Romaniei - Determinarea si descrierea speciilor spontane si cultivate, vol.I-II, Editura Ceres, Bucuresti, 19881990, p. 331.

7.SARBU, I., STEFAN N., IVANESCU L., MANZU C., Flora ilustrata a plantelor vasculare din estul Romaniei, vol.I-II, Editura Univ. Alex.I.Cuza, Iasi, 2001, p. 252.

8.VELICKOVIC, J. M., KOSTIC, D. A., STOJANOVIC, G. S., MITIC, S. S., MITIC, M. N., RANDELOVIC, S. S., DORDEVIC, A. S., Hem. Ind., 2014, 68, no. 3, p. 297-303.

9.RADOVANOVIC, B., C., ANDELKOVIC, S. M., RADOVANOVIC, A. B., ANDELKOVIC, M. Z., Trop. J. Pharm. Res., 2013, 12, no. 5, p. 813819.

10.SIKORA, E., BIENIEK, M. I., BORCZAK, B., Acta. Sci.Technol., 2013, 12, no. 4, p. 365-372.

11.ALEXAN, M., BOJOR O., CRACIUN F., Flora medicinala a Romaniei, vol.II, Editura CERES, Bucuresti, 1991, p. 117-118.

12.***Farmacopeea Romana Editia a 10-a, Editura Medicala, Bucuresti, 1993, p. 67-68, p. 335, p. 419-421, p. 921-922, p. 951-952, p. 1006-1016, p. 1018-1019, p. 1051-1065, p. 1124-1162.

13.***The European Pharmacopoeia, 2017, Edition 9.0., EDQM, Volume I, p. 288.

14.MIHAI, S., DUMITRESCU, D., RADUCANU, M., STOICESCU, I., BADEA, V., Rev. Chim., 70, no.1, 2019, p. $23-26$.

15.MINSHI, L., XICAN, L., XIAOJIAN, O., HONG, X., Molecules, 2019, 24, no. 1, p. 3.

16.ISTUDOR, V., Farmacognozie, Fitochimie, Fitoterapie, vol.I, Editura Medicala, Bucuresti, 1998, p. 28 , p. 188.

17.PINACHO, R., CAVERO R.,Y., ASTIASARAN, I., ANSORENA, D., CALVO M., I., J. Funct. Food., 2015,19 , p. $49-62$.

18.NATIC, M., PAVLOVIC, A., LOBOSCO, F., STANISAVLJEVIC, N., ZAGORAC, D.D., AKSIC, M.F., PAPETTI, A., Eur. Food Res. Technol., 245, no. 2, p. 469-478. 
19.LIU, M., SONG, S., LI, H., JIANG, X., YIN, P., WAN, C., \& XU, J., J. Dairy Sci., 2014, 97, no. 5, p. 2856-2865.

20.MENG, S., CAO, J., FENG, Q., PENG, J., \& HU, Y., Evid.-Based Compl. Alt., 2013, p. 1-11.

21.KIM, J. H., LEE, H. O., CHO, Y. J., KIM, J., CHUN, J., CHOI, J., LEE, Y., JUNG, W. H., Plos One, 2014, 9, no. 2 , p. 18.

22.RUIZ-RODRIGUEZ, M., ANCOS, B. D., SANCHEZ-MORENO, C., FERNANDEZ RUIZ, V., SANCHEZ MATA, M. C., TARDIO, J., Fruits, 2014, 69, no. 1, p. 61-73.

23.CELIK, F., GUNDOGDU, M., ALP, S., MURADOGLU, F., ERCISLI, S., GECER, M.K., CANAN, I., Acta Chromatogr., 29, no. 4, p. 507-510.

Manuscript received: 1.04 .2019 